\title{
EFFECT OF DAYLIGHT HOURS ON PERFORMANCE OF GROWING GRASSCUTTERS
}

\author{
G. S. I. WOGAR, L. N. AGWUNOBI AND B. E. UBOM
}

(Received 1, November 2011; Revision Accepted 15, March 2012)

\begin{abstract}
The grasscutter (Thryonomysswinderianus) holdspromise as a source of increased protein for populations of Sub-Sahara African countries. It is inexpensive to feed and features the feed utilization characteristics of ruminants and monogastrics. It is nocturnal in its activities, especially feeding. This experimentwas carried out to determine the effect of daylight hours or photoperiod on growing grasscutters under intensive rearing conditions. The effect of daylight hours on growing grasscutters was determined using sixteen 8-months old femalegrasscutters. The grasscutters were separated into four groups and allotted to four treatments of varying daylight hours. The treatments included; zero (0) hours of daylight and twenty four (24) hours $(6.00 \mathrm{am}-6.00 \mathrm{am})$ of darkness (0L:24D), six antemeridiem (am) hours (6.00 am-12.00 noon) of daylight and eighteen (18) hours (12.00 noon-6.00 am) of darkness (6L(am):18D), six post-meridiem (pm) hours (12.00 noon-6.00 pm) of daylight and eighteen (18) hours (6.00 pm-12.00 noon) of darkness (6L(pm):18D) and twelve (12) hours $(6.00 \mathrm{am}-6.00 \mathrm{pm})$ of daylight and twelve (12) hours (6.00pm$6.00 \mathrm{am}$ ) of darkness (12L:12D).Allgrasscutters were fedadiet containing 2200kilocalories metabolizable energy per kilogram (KcalME/kg) and crude protein (CP) level of $20 \%$. Cassava root meal and wheat offalwere the main sources of energy, while soybean meal was the main source of protein in the diets. Elephant grass was fed as basal diet.The results showed thatforage, concentrate (diet) and total feed intake, and daily weight gain were significantly $(P<0.05)$ higher under the 6 post-meridiem hours of daylight and 18 hours of darkness $(6 \mathrm{~L}(\mathrm{pm}): 18 \mathrm{D})$ than under other conditions. It was, therefore, concluded that the optimum daylight conditions required for the rearing of growing grasscuttersare the six (6) hours of post-meridiem daylight, followed by eighteen (18) hours of darkness.
\end{abstract}

KEY WORDS: Daylight hours, Photoperiod, Performance, Grasscutters

\section{INTRODUCTION}

The farming of grasscutter offers promiseof less expensive intervention, in the supply of animal protein in thediets of the populations of the countries of SubSahara Africa, than is possible with conventional livestock. Presently, most African diets consist of starchy foods, which are highly deficient in protein (African Farming, 1996). The challenge of protein deficiency can be mitigated by the farming of unconventional livestock such as the grasscutter.

An importantfactor in favour of the intensive farming of thegrasscutter (Thryonomysswinderianus) is its biological efficiency. The grasscutter is an efficient converter of almost any form of roughage (Pich and Peters, 1985) because of its specialized digestive system (Emmons, 1987). This makes it an important animal in the drive to produce animal protein using less expensive feedstuffs. The utilization of fibre diets by microbes of the caecum of the grasscutter is similar to that of rumen microbes. Fibreand simple nitrogen compounds are converted to volatile fatty acids (Michalet-Doreau, 2002) and microbial cells, which serve as precursors for much of the metabolizable energy (Kristensen 2005) and other chemical components of the body.
The grasscutter is actively nocturnal and is killed by hunters and trappersfrom the wildfor 'bushmeat'. The 'bushmeat' market is dominated by grasscutter (Falconer, 1992), which provides an estimated $20 \%$, and accounts for about $0.5 \mathrm{~g}$ per caput per day intake, of animal protein in Nigeria (FAO, 1995).Grasscutter meat is an important source of protein and a cherished delicacy in all cultures (Joriet al., 1995) in the West African Sub-region. The popularity of its meat in West Africa is generating great interest in the farming of grasscutter.Intensive production of the grasscutter requires, not only an adequate knowledge of its nutritional requirements but also an adequate understanding of its requirements as a nocturnal animal.

The nocturnal activities of thegrasscutter are determined by changes indaylength or photoperiod. Photoperiod depends on the rotation of the earth around the sun anddetermines the time of the year (Gwinner, 1986). The biologically controlled rhythm in theactivities of many organisms, known ascircadian rhythms, are based on biological clocks, whichare synchronized by photoperiod (Bromageet al., 1993). In the temperate regions, photoperiod serves as the trigger of various processes such as hibernation in mammals, migration in birds and breeding cycles for most mammals (Gwinner, 1986).

G. S. I. Wogar, Department of Animal Science, University of Calabar, Calabar, Cross River State, Nigeria.

L. N. Agwunobi, Department of Animal Science,University of Calabar, Calabar, Cross River State, Nigeria.

B.E. Ubom, Department of Animal Science, University of Calabar, Calabar, Cross River State, Nigeria. 
It has been found that photoperiod induces the secretion of melatonin in the night and that the mechanisms and effects of photoperiod-controlled rhythmicity are best known in vertebrates (Sumpter, 1990). Melatonin is produced in the pineal gland (Peter, 1983 ) and by a variety of peripheral cells such as bone marrow cells (Maestroni, 2001), lymphocytes and epithelial cells of most animals. It plays a role in the regulation of circadian rhythms of several biological functions (Altun and Ugur-Altun, 2007). Melatonin functions through the activation of melatonin receptors (Boutinet al., 2005) and through its role as a pervasive and powerful antioxidant (Hardeland, 2005) particularly important in the protection of nuclear and mitochondria DNA.Many animals use the daily variation in the duration and quantity of melatonin production as a seasonal clock (Lincoln and Loudon, 2003). The change in the duration of secretion serves as a biological signal for the organization of daylength-dependent functions such as reproduction, behavior, coat growth and camouflage colouring in some animals (Arendt and Skene, 2005).

Circadian rhythms involve an approximate daily or 24-hour cycle of chemical, physiological and behavioral processes in the biological system. The physiological reaction todaylight hours and the role of the circadian system is vital to the organism (Zivkovic, 2007). Feed intake by animals is affected by photoperiod. Tucker et al.(1984) found that increasing daily exposure to light increased feed intake when sheep or cattle were fed ad libitum. Lactating cows exposed to long day photoperiod (LDPP) have been shown (Dahl and Petitclerc, 2003) to have higher dry matter intake (DMI) than those without extended light exposure. It has been reported (Dahl et al., 2000) that lactating cows exposed to 16-18 hours of daylight (i.e. long day photoperiod-LDPP) have greater milk yield than those on a typical light schedule of natural photoperiod. Other studies have shown that differences in the response to daylength exposure or photoperiod are determined by the physiological status (Auchtunget al.,2005), age (Zinnet al.,1986) or species (Tucker et al., 1984) of the animal.For now, no literature has been found on the effect of photoperiod on the growth and reproductive performance of grasscutters.

The grasscutter is active during night hours and spends the daylight hours sleeping or resting. The length ofdaylight hours of exposure could affect the chemical and physiological basis of grasscutterbehaviour and, therefore, the performance of grasscutter. The objective of this study was, therefore, to investigate the growth performance of intensively rearedgrasscutters under varying daylight conditions.

\section{MATERIALS AND METHODS}

The study was carried out at the Grassccutter Research Farm inCalabar, in the Department of Animal Science, University of Calabar, Calabar, Nigeria. Calabar is at latitude $3^{0}$ Northand longitude $7^{0}$ East. It has an annual rainfall of 2650 to $3000 \mathrm{~mm}$ and relative humidity of 57 to $93 \%$. The annual temperatures are between 25 and $32^{\circ} \mathrm{C}$ (Calabar Travel Guide, 2010). The study, which lasted for twelve (12) weeks, was conducted during the late Dry Season between the months of January and April, 2009.

\section{Experimental diets}

The grasscutter diet was formulated to supply dietary energy content of 2200kilocalories metabolizable energy per kilogram (KcalME/kg) and crude protein (CP) level of $20 \%$. Cassava root meal and wheat offal served as the sources of energy, while soybean meal was the main source of protein in the diets.Cassava also served as a binding agent in the diet. Elephant grass was fed as the basal diet. The energy contents of the diets were calculated from the energy density of each ingredient of the diets. All the ingredients used were purchased from a local market in Calabar. A thick paste of the ingredients was pelleted in a pelleting machine and dried in a kerosene-fired oven at $75^{\circ} \mathrm{C}$. The composition of the test diet is shown in Table 1, while the proximate composition of the diet is shown in Table 2.

\section{Research animals}

Sixteen (16)growing grasscutters aged 8 months, average weight of $1.59-2.00 \mathrm{~kg}$ were used in the study. They were individually housed in clearlylabelled concrete cells measuring $150 \times 75 \times 35 \mathrm{~cm}$ (length $\mathrm{x}$ width $\mathrm{x}$ height). The housing provided for only one opening ( 35 high $\times 45 \mathrm{~cm}$ wide) into the cell in order to eliminate cross-ventilation and prevent the adverse effect of cold on them as they are susceptible to pneumonia.By boarding up the only opening (or door) into each cell with paper boards, which were cut from cartons, it was possible to create darkness in the cells. The temperatures in the cells were in the range of $28-33^{\circ} \mathrm{C}$ during the experimental period.

The grasscutters were randomly allotted in groups of four to four daylight hours treatments;zero (0) hours of daylight and twenty four (24) hours (6.00 am$6.00 \mathrm{am}$ ) of darkness (0L:24D), six ante-meridiem (am) hours (6.00 am-12.00 noon) of daylight and eighteen (18) hours (12.00 noon-6.00 am) of darkness (6L(am):18D), six post-meridiem (pm) hours (12.00 noon-6.00 pm) of daylight and eighteen (18) hours (6.00 $\mathrm{pm}-12.00$ noon) of darkness $(6 \mathrm{~L}(\mathrm{pm}): 18 \mathrm{D})$ and twelve (12) hours (6.00 am-6.00 pm) of daylight and twelve (12) hours $(6.00 \mathrm{pm}-6.00 \mathrm{am})$ of darkness (12L:12D). The 6 postmeridiem hours of daylight and the 18 hours of darkness in this study involved the extension of night hours by 6 antemeridiem dark hours, while the 6 antemeridiem hours of daylight and 18 hours of darkness involved creating 6postmeridiem dark hours before the night hours.

Each group was liberally fed the concentrate diet. There were four replicates per treatment, with one (1) grasscutter per replicate.The growing grasscutters were fed the test diet along with elephant grass (Pennisetumpurpureum) for one week before data collection. This was to minimise stress that could be caused by the change in diet. The animals were dewormed and provided with anti stress agents in drinking water before commencement of experiment. Elephant grass (Pennisetumpurpureum) was fed daily as basal diet after it had been cut and allowed to wilt for two days. Water, diet and elephant grass were supplied ad libitum.

The animals were weighed at the beginning and every two weeks thereafter during the study period. All cells were cleaned daily in order to ensure an acceptable level of sanitation. 


\section{Data collection and statistical analysis}

Data collection on: daily forage intake (g); daily forage dry matter intake (g), which was estimated as $12 \%$ Dry Matter content of elephant grass; daily diet intake (g); daily total feed intake $(\mathrm{g})$, which was the total intake of forage dry matter and concentrate; daily weight gain of growing grasscutters and cost of concentrate (N.K) served as the parameters.
They were randomly allocated to the four daylight hours treatments. The design of the experiment was the Completely Randomized Design. All the data collected were subjected to analysis of variance using the Genstat (2007) software. Significant means were separated using Duncan's Multiple Range test (Steel and Torrie, 1980).

Table 1: Composition of Experimental Diet for Growing Grasscutters.

\begin{tabular}{|lc|}
\hline Ingredients & \% Composition \\
\hline Cassava 27.00 & \\
Soybean meal & 9.00 \\
Palm kernel cake & 40.00 \\
Wheat offal & 20.00 \\
Vitamin premix & 0.50 \\
Bone meal & 3.00 \\
Salt & 1.00 \\
& \\
& \\
& \\
\hline Total & \\
\hline
\end{tabular}

Table 2: Proximate Composition of Experimental Diet

\begin{tabular}{|lc|}
\hline Nutrients & Composition (DM) \\
\hline Crude protein & 18.56 \\
Crude fibre & 9.50 \\
Ether extract & 4.75 \\
Ash & 4.10 \\
Nitrogen free extract & 49.24 \\
Dry matter & 86.15 \\
Metabolizable energy (kcalME/kg) & 2,226 \\
\hline
\end{tabular}

\section{RESULTS AND DISCUSSION}

The effects of varying daylight hours on the performance of the growing grasscutters are presented in Table 3.

\section{Growth Performance}

Forage intake: The resultsindicate that forage intake was significantly $(P<0.05)$ higheringrasscutters raised under the 6 postmeridiem daylight hours and 18 hours of darkness $(6 \mathrm{~L}(\mathrm{pm}): 18 \mathrm{D})$ than in those raised under other daylight conditions.

The lowest forage intake was observed under conditions providing 24 hoursof darkness((OL:24D). This finding suggests the need for, and importance of daylight in the foraging activity of growing grasscutters.
Forage intake ingrasscutters raised under the 12 hours of daylight and 12 hours of darkness (12L:12D) was lower than forage intakeingrasscutters raisedunder the 6 postmeridiem daylight hours and 18 hours of darkness $(6 \mathrm{~L}(\mathrm{pm}): 18 \mathrm{D})$. This finding suggests that the 12 hours of daylight was higher than the maximum of 6 hours of daylight required by growing grasscutters for optimum forage intake.

Significant $(P<0.05)$ differences were observed between grasscutters raised under the 6 antemeridiem hours of daylight and 18 hours of darkness (6L(am):18D)and those raised under the 6 postmeridiem hours of daylight and 18 hours of darkness (6(pm):18D). It was found that though each of the two treatments provided 6 hours of daylight and 18 hours of darkness, forage intake was significantly $(P<0.05)$ higher ingrasscutters raised under conditions, which included the 6 postmeridiem hours of daylight (6L(pm):18D). 
These findings suggest that under the conditions of this study, 6 postmeridiem daylight hours followed by 18 hours of darkness provided optimum conditions for forage intake by growing grasscutters. It was also noted that the significantly $(P<0.05)$ higher forage intake during the 18 hours of darkness under the $6 \mathrm{~L}(\mathrm{pm}): 18 \mathrm{D}$ conditions included the extention of thedark foraging hours by 6antemeridiem hours. This finding is important as foraging constitutes a primary activity and highlights the observation that darkantemeridiem hours are necessary for optimizing the foraging activities of grasscutter.

Diet (concentrate) intake: In the wild, intake of concentrate feedstuffs (roots and tubers, cereals, berries, nuts) is part of the foraging and browsing activity of the grasscutter. The results of this study indicate that concentrate intake was significantly $(P<0.05)$ higher ingrasscutters raised under the 6 postmeridiem daylight hours and 18 hours of darkness $(6 \mathrm{~L}(\mathrm{pm}): 18 \mathrm{D})$ than in those raised under other daylight conditions.

It was observed that concentrate intake under the $6 \mathrm{~L}(\mathrm{am}): 18 \mathrm{D}$ and 12L:12D conditions, which involved6antemeridiem daylight hours and 12 daylight hours respectively, was significantly $(P<0.05)$ lower than under the $6 \mathrm{~L}(\mathrm{pm}): 18 \mathrm{D}$ and $0 \mathrm{~L}: 24 \mathrm{D}$, which involved theextention of night hours by6antemeridiem dark hours and 12dark hours respectively. These observations suggest that the significantly $(P<0.05)$ higher concentrate intake during the 18 and 24 hours of darkness under the $6 \mathrm{~L}(\mathrm{pm}): 18 \mathrm{D}$ and $\mathrm{OL}: 24 \mathrm{D}$ conditions, respectively were due to the extention of night hours by 6 to 12 darkhours. This finding highlights the observation that dark hours are important in optimizing concentrate intake by grasscutter.

Total feed intake: The results of this study indicate that total feed intake was significantly $(P<0.05)$ higher ingrasscutters raised under the 6 postmeridiem daylight hours and 18 hours of darkness $(6 \mathrm{~L}(\mathrm{pm}): 18 \mathrm{D})$ than ingrasscutters raised under other daylight conditions. The results underscore the importance of daylight conditions, which include 18 hours of darkness (specifically, from $6.00 \mathrm{pm}$ to 12.00 noon) and 6 daylight hours (specifically, from 12.00 noon to $6.00 \mathrm{pm}$ ) for foraging and feeding by growing grasscutters.

The findings of this study indicate that the effects of photoperiod on feed intake of growinggrasscutter are determinedby specific durationand time of exposure to daylight hours. These results suggest that short daylight hours, specifically the 6 daylight hours of 12.00 noon to $6.00 \mathrm{pm}$ followed by 18 hours of darkness increased feed intake in growing grasscutters. Studies with other animals are more concerned with duration than with time of exposure to daylight hours. Tucker et al.(1984) found that increasing daily exposure to light increased feed intake when sheep or cattle were fed ad libitum. Similarly, lactating cows exposed to long day photoperiod were found to have higher dry matter intake (DMI) than those without extended light exposure (Dahl and Petitclerc, 2003). The results of this study show that while daylight hours were important for increased feed intake, the dark hours immediately following daylight exposure were equally as important.

Average daily weight gain: Average daily weight gain was significantly $(P<0.05)$ higher ingrasscutters raised under the 6 postmeridiem daylight hours and 18 hours of darkness $(6 \mathrm{~L}(\mathrm{pm}): 18 \mathrm{D})$ than ingrasscutters raised under other daylight conditions. The higher average daily weight gain ingrasscutters under the $6 \mathrm{~L}(\mathrm{pm}): 18 \mathrm{D}$ daylight conditions could be due to the higher intake of forage and concentrate. It was observed that the 6 daylight hours and 18 hours of darkness supportedthe higher average daily weight gain, and that the 6 postmeridiem daylight hours of 12.00 noon to $6.00 \mathrm{pm}$ probably contributed to the higher daily weight gain. The observed requirement of 6 postmeridiem daylight hours and 18 hours of darkness involved the extension of the night hours by 6 antemeridiemdark hours (from $6.00 \mathrm{am}$ to 12.00 noon). Average daily weight gain was reduced underall otherdaylight conditions.

The findings of this study indicate that the effects of photoperiod on average daily weight gain of growing grasscutter are probably determined by specific duration and time of exposure to daylight hours.. Theseresults suggest that short daylight hours, specifically the 6 daylight hours of 12.00 noon to 6.00 pm followed by 18 hours of darkness could increase daily weight gain in growing grasscutters.Studies with unrelated animals are more concerned with duration, than with time, of exposure to daylight hours. The findings of studies (Zinn et al., 1986) with other animals indicate that photoperiod did not affect average daily weight gain in prepubertal Holstein heifers, while postpubertal heifers exposed to short day photoperiod (SDPP) had greater average daily weight gain than those exposed to long day photoperiod (LDPP).Increasing daylight exposure from 8 to 16 hours has been found to increase average daily weight gain of sheep and Holstein cattle but reduced gains of whitetailed doe fawns (Tucker et al., 1984). The average daily weight gain of growing grasscutters $(8.53 \mathrm{~g})$ under the 6 postmeridiem daylight hours was within the 8 to $13 \mathrm{~g}$ range reported by Jori and Chardonnet (2001) and 7 to $12 \mathrm{~g}$ reported by Mensah (1995) for grasscutters under natural photoperiod.

The results of this study show that while the 6 postmeridiem daylight hours were important for increased average daily weight gain, the 18 dark hours immediately following the daylight exposure were equally very important.

Feed conversion ratio; Cost togain ratio: The amount of feed consumed by growing grasscutters per unit weight gain (or feed conversion ratio) did not differ significantly among grasscutters from the different treatments. Similarly, the cost to gain ratio of raising growing grasscuttersdid not differ significantly between the different treatments. 
Table 3: Performance of Growing Grasscutters under Varying Daylight Hours

\begin{tabular}{|llcccc|}
\hline Parameters & 0L:24D & $\mathbf{6}(\mathbf{a m}): \mathbf{1 8 D}$ & $\mathbf{6 L}(\mathbf{p m}): \mathbf{1 8 D}$ & $\mathbf{1 2 L}: \mathbf{1 2 D}$ & SEM \\
\hline Initial weight of grasscutters $(\mathrm{g})$ & 1767.50 & 1770 & 1770 & 1770 & 45.60 \\
Final weight of grasscutters $(\mathrm{g})$ & 2402.50 & 2326.67 & 2543.33 & 2402.50 & 69.10 \\
Average daily forage intake $(\mathrm{g})$ & $306.90^{\mathrm{c}}$ & $313.70^{\mathrm{bc}}$ & $377.60^{\mathrm{a}}$ & $346.00^{\mathrm{ab}}$ & 13.10 \\
Average daily forage dry matter intake $(\mathrm{g})$ & $38.35^{\mathrm{c}}$ & $39.22^{\mathrm{bc}}$ & $47.20^{\mathrm{a}}$ & $43.25^{\mathrm{ab}}$ & 1.64 \\
Average daily diet intake (g) & $68.80^{\mathrm{ab}}$ & $63.20^{\mathrm{b}}$ & $75.90^{\mathrm{a}}$ & $62.10^{\mathrm{b}}$ & 2.68 \\
Average daily total feed intake (g) & $105.70^{\mathrm{b}}$ & $101.40^{\mathrm{b}}$ & $121.80^{\mathrm{a}}$ & $104.10^{\mathrm{b}}$ & 2.90 \\
Average daily weight gain (g) & $7.56^{\mathrm{b}}$ & $6.21^{\mathrm{c}}$ & $8.53^{\mathrm{a}}$ & $7.53^{\mathrm{b}}$ & 1.04 \\
Feed conversion ratio & 17.10 & 23.20 & 19.80 & 14.80 & 5.40 \\
Average daily cost of diet (N.K/day) & $3.85^{\mathrm{ab}}$ & $3.53^{\mathrm{b}}$ & $4.25^{\mathrm{a}}$ & $3.48^{\mathrm{b}}$ & 0.15 \\
Cost per unit gain (N.K/g) & 0.63 & 0.86 & 0.71 & 0.48 & 0.21 \\
\hline
\end{tabular}

1 . ${ }^{\mathrm{abc}}$ Means along the same row having no common superscript differ significantly at $\mathrm{P}<0.052$. N.K $=$ Naira.Kobo (Nigerian currency; N155.00 = US\$1.00)

\section{CONCLUSION}

The results of this study indicate that average daily forage intake, average daily concentrate intake, and average daily weight gain increased when growing grasscutters were exposed to 6 postmeridiem daylight hours (specifically from 12.00 noon to $6.00 \mathrm{pm}$ ) followed by 18 hours of darkness. These findings suggest that while a photoperiod of 6 postmeridiemdaylight hours was important for increased growth performance, the 18 dark hours immediately following the daylight exposure were equally very important.It was, therefore, concluded that the optimum daylight conditions required for the rearing of growing grasscutterswere the six (6) hours of post-meridiem daylight followed by eighteen (18) hours of darkness.

\section{REFERENCES}

African Farming, 1996. Allain Charles Publishing Ltd., London, 9 - 11.

africanfarming.net/.../agriculture/230-the-issueof-food-security.html

Altun, A. and Ugur-Altun, B., 2007. Melatonin: Therapeutic and clinical utilization. Int. J.Clin. Pract., 61(5): 855 - 45. onlinelibrary.wiley.com/doi/10.1111/j.17421241. 2006.01191.x/full

Arendt, J. and Skene, D. J., 2005. Melatonin as a chronobiotic.Sleep Med. Rev. 9(1): 25 - 29. www.primarypsychiatry.com/aspx/articledetail.a spx?articleid $=1563$

Auchtung, T. A., Rius, A. G., Kendall, P. E., McFadden,

T. B. and Dahl, G. E., 2005. Effect of photoperiod during the dry period on prolactin, prolactin-receptor and milk production of dairy cows. Journal Dairy Sci. 88: 121 - 127.

joe.endocrinology-journals.org/externalref?access...Auchtung\%20T
Boutin, J., Audinot, V., Ferry, G.andDelagrange, P., 2005. Molecular tools to study melatonin pathways and actions. Trends Pharmacol. Sci. 26 (8): 412 - 9. $w w w . j b c . o r g / e x t e r n a l r e f ? a c c e s s \_n u m=A u d i n o t \%$ 20V\&link_type

Bromage,N., Randall,C., Duston, J., Ilnush, M. and Jones, J., 1993. Environmental control of reproduction in salmonoids. In: Muir, J. F. and R. J. Roberts (Eds). Recent Advances in Aquaculture. Vol. 4. Oxford-Uk Blackwell Scientist Publications, 5565. jeb.biologists.org/content/209/12/2249.full

Calabar Travel $\quad$ Guide., 2010. www.cometonigeria.com/nigerian-cities-andtowns/calabar

Dahl, G. E., Buchanan, B. A. and Tucker, H. A., 2000. Photoperiod effects on dairy cattle: A review. J. Dairy Sci. 83: $885 \quad$ - 893. www.omafra.gov.on.ca/english/.../dairy/.../info_p hotoperiod.htm

Dahl, G. E. andPetitclerc, D., 2003. Management of photoperiod in the dairy herd for improved production and health. J. Anim. Sci. 81(Suppl. 3): 11-17.

www.asas.org/symposia/03supp3/11.pdf

Emmons, L. H., 1987. Ecological considerations on the farming of game animals: capybaras yes, pacas no. Vida Silvestre Neotropical 1: 54 - 55. www.mnh.si.edu/vz/...staff.../emmons_louise_pu blicationlist.cfm

Falconer,J., 1992. People's and trade in non-timber forest products in Southern Ghana: A pilot study report prepared for the Overseas Development Administration. www.fao.org/docrep/w7540e/w7540e0k.htm 
FAO. 1995., Synopsis of the special programme on food production in support of food security inlow income food deficit countries (LIFDC). Food and Agricultural Organization,

Rome.www.mofa.go.jp/region/africa/ticad2/list98 /s_economic/2_3_8.html

Genstat., 2007. Lawes Agricultural Trust.Rothamsted Experimental Station, England. www.vsn.co.uk/software/genstat/

Gwinner, E., 1986. Circannual Rhythms.Zoophysiology 18. Heidelberg: Springer-Verlag www.opefe.com/colossoma.html

Hardeland, R.., 2005. Antioxidative protection by melatonin: Multiplicity of mechanisms from radical detoxification to radical avoidance. Endocrine, 27 (2): 119 - 130.

www.ncbi.nlm.nih.gov/pubmed/16217125

Jori, F. and Chardonnet P., 2001. Cane rat farming in Gabon; status and perspective. Proceedings of the $5^{\text {th }}$ International Wildlife Ranching Symposium, March 2001, Pretoria, South Africa, $33-51$.

www.medwelljournals.org/qredirect.php?doi=aja s. 0000.32720

Jori, F., Mensah, G. A. and Adjanohoun, E., 1995. Grasscutter production: an example of rational exploitation of wildlife. Biodiversity and Conservation, 4: 257 - 267.

www.iucnredlist.org/apps/redlist/details/21847/0/ biblio

Kristensen, N. B., 2005. Splanchnic metabolism of volatile fatty acids in the dairy cow. Animal Science, 80: 2 - 9.

www.bsas.org.uk/Publications/Animal_Science/ 2005/Volume_80.../pdf

Lincoln, G., Andersson, H and Loudon, A., 2003. Clock genes in calendar cells as the basis of annual time keeping in mammals - a unifying hypothesis. J. Endocrinology, 179 (1): $1-13$ joe.endocrinologyjournals.org/content/179/1/1.a bstract

Maestroni,G. J., 2001. The immunotherapeutic potential of melatonin.Expert.Opin investing drugs, 19 (3): $467-476$.

informahealthcare.com/doi/abs/10.1517/135437 84.10.3.467\%20 Mensah, G.A., 1995. Feed intake and digestibility in grasscutters
(Thryonomysswinderianus). Tropicultura, 13:www.medwelljournals.org/fulltext/?doi=ajas. 0 $000.32720 \ldots$ org...

Michalet-Doreau, B., 2002. A comparison of enzymatic and molecular approaches to characterizethe cellulolytic microbial ecosystems of the rumen and the caecum. J. Anim. Sci., 80: 790 - 796. jas.fass.org/content/80/3/790.full.pdf

Pich, S. and Peters, K. J., 1985. Possibilities of using cane cutter for meat production in Africa. Unpublished manuscript. Institute of Animal Breeding, University of Gottingen, FRG.www.nap.edu/openbook.php?record_id=18 31\&page

Steel, R. G. D. and Torrie. J. H., 1980. Principles and Procedures of Statistics - A Biometrical Approach, $2^{\text {nd }} e d n$, McGraw Hill Book Co., New York. 137 - 171.

www.sciencedirect.com/science/article/pii/00936 91X9390319Z

Sumpter, J. P., 1990. General concepts of seasonal reproduction. In: Muro, A. D., A. P. Scott and T. J. Lam (Eds.). Reproductive seasonalities in Teleosts: Environmental Influences. CRC. Press, Boca Raton, Florida. 13 - 32. aquafind.com/articles/Fish-Photoperiodism.php

Tucker, H. A., Petitclerc, D. and Zinn, S. A., 1984. The influence of photoperiod on body Weightgain, body composition, nutrient intake and hormone secretion.Review.PubMed. PMID. 59 (6): $1610-20$.

www.ncbi.nlm.nih.gov/sites/entrez?itool=pubme d...Cmd

Zinn, S. A., Purchas, R. W., Chapin, L.T.,Petitclerc, D., Merckel, R. A. Bergen, W. G and Tucker, H. A.,1986. Effect of photoperiod on growth, carcass composition, prolactin, growthhormone and cortisol in prepubertal and postpubertal Holstein heifers. J. Anim. Sci. 63: 1804 -1815. jas.fass.org/externalref?access_num $=3366708 \&$ link_type=MED

Zivkovic, B. 'Coturnix'. 2007. Clock Tutorial No. 16: Photoperiodism - models and experimental approaches. In: A blog around the clock. Science Blogs. Web link: www.wikipedia-org'sunlight' 